\title{
Indeks Eritrosit Anak Babi (Sus scrofa) yang Diinduksi Sepsis Pascaresusitasi Cairan
}

\author{
Muhammad Abhi Purnomosidi ${ }^{1}$, Rismala Dewi ${ }^{2}$, Gunanti $^{3}$, Riki Siswandi ${ }^{3}$, Dwi Utari Rahmiati ${ }^{3}$ \\ ${ }^{1}$ Program Sarjana Fakultas Kedokteran Hewan, Institut Pertanian Bogor \\ ${ }^{2}$ Program Pascasarjana Fakultas Kedokteran, Universitas Indonesia \\ ${ }^{3}$ Departemen Klinik Reproduksi dan Patologi, Fakultas Kedokteran Hewan, Institut Pertanian Bogor
}

ABSTRAK: Penelitian ini bertujuan untuk mengevaluasi indeks eritrosit (jumlah eritrosit, konsentrasi hemoglobin, hematokrit, VER, HER, KHER) pada anak babi (Sus scrofa) setelah diinduksi sepsis dan diresusitasi oleh cairan koloid (modified fluid gelatin 4\%) atau kristaloid (ringer asetat malat). Sepuluh ekor anak babi berumur 2-3 bulan dengan berat badan 8-13 kg dibagi menjadi dua kelompok. Induksi sepsis dilakukan dengan injeksi endotoksin Eschericia coli melalui rute intravena hingga terjadi renjatan sepsis. Resusitasi cairan dilakukan pada saat renjatan sepsis terjadi melalui rute intravena. Kelompok pertama menerima resusitasi cairan menggunakan modified fluid gelatin 4\% (MFG 4\%) dan pada kelompok yang kedua menerima resusitasi cairan menggunakan cairan ringer asetat malat (RAM). Pengambilan sampel darah dilakukan pada saat setelah anestesi, saat sepsis, dan 3 jam setelah resusitasi cairan. Hasil evaluasi nilai indeks eritrosit menunjukkan bahwa hewan mengalami anemia makrositik regeneratif. Kondisi sepsis dan resusitasi cairan koloid (modified fluid gelatin 4\%) maupun cairan kristaloid (ringer asetat malat) tidak memberikan pengaruh yang signifikan terhadap nilai indeks eritrosit.

Keywords:

anak babi, indeks eritrosit, koloid, kristaloid, sepsis

\section{- PENDAHULUAN}

Sepsis merupakan keadaan klinis yang ditandai oleh sindrom respon inflamasi sistemik (systemic inflammatory response syndrome/SIRS). Kondisi sepsis dapat menyebabkan terjadinya kerusakan sel endotelial mikrovaskular serta pelepasan mediator inflamasi oleh sel endotel. Kerusakan sel endotelial menyeluruh menyebabkan peningkatan permeabilitas sehingga timbul edema dan kehilangan cairan yang cukup banyak ke jaringan interstisial (Vincent dan Abraham 2006).

Resusitasi cairan merupakan tata laksana terkini untuk sepsis yang bertujuan mengoptimalkan hemodinamik dalam 6 jam pertama yang dikenal sebagai early goal directed therapy. Sampai saat ini masih menjadi kontroversi mengenai pemilihan cairan kristaloid atau koloid sebagai cairan resusitasi yang ideal (Dewi 2015). Pemeriksaan indeks eritrosit merupakan bagian dari pemeriksaan darah lengkap (complete blood count). Pemeriksaan darah lengkap dilakukan untuk menunjang diagnosa suatu penyakit, mengetahui adanya kelainan maupun perubahan pada darah akibat infeksi sistemik, dan melihat kemajuan atau responterapi pada pasien yang menderita suatu penyakit infeksi (Voigt dan Swist 2011).

\section{- MATERI DAN METODE}

Penelitian ini menggunakan anak babi (Sus scrofa) jantan danbetina berumur 2-3 bulan dengan berat badan $8-13 \mathrm{~kg}$ sebanyak 10 ekor dan terbagi menjadi dua kelompok (5 ekor anak babi untuk perlakuan dengan resusitasi modified fluid gelatin 4\% (MFG 4\%) dan 5 ekor anak babi untuk perlakuan dengan resusitasi cairan ringer asetat malat (RAM)). Penelitian ini telah disetujui oleh komisi etik hewan IPB dengan nomor persetujuan kode etik FRM/FKH/000-78.

Tahap perlakuan dimulai dengan induksi anestesi menggunakan kombinasi ketamine $10 \%$ dan xylazine $2 \%$ dengan rute pemberian intramuskuler. Setelah itu dilakukan pemasangan kateter vena sentral pada vena cava cranialis dan kateter arteri pada arteri femoralis sebagai tempat sensor alat $\mathrm{PiCCO}{ }^{\circledR}$. Maintenance anestesi dengan pemberian ketamine secara berkelanjutan dengan syringe pump. Kemudian diinduksikan endotoksin $50 \mathrm{ug} / \mathrm{kg}$ berat badan melalui kateter vena sentral dan dilakukan pemantauan gejala sepsis yaitu demam (suhu tubuh $>39.8$ ${ }^{\circ} \mathrm{C}$ ), takikardia (frekuensi jantung > $120 \mathrm{kali} /$ menit) dan takipnea (frekuensi napas > $58 \mathrm{kali} /$ menit). Pemantauan selanjutnya adalah tanda-tanda renjatan sepsis (shock septic) yang dilihat dari extravascular lung water index $($ ELWI) > $10 \mathrm{ml} / \mathrm{kg}$ berat badan, takikardia, waktu pengisian kapiler $\geq 3$ detik, dan ekstremitas dingin. Setelah tanda-tanda renjatan sepsis terlihat, dilakukan resusitasi $\begin{array}{ll}\text { Diterima } & : 28 \text { Juli } 2017 \\ \text { Direvisi } & : 14 \text { Agustus } 2017 \\ \text { Disetujui } & \text { : } 16 \text { Agustus } 2017\end{array}$ 
modified fluid gelatin 4\% (MFG4\%) atau cairan ringer asetat malat (RAM) sebanyak $20 \mathrm{ml} / \mathrm{kg}$ berat badan melalui kateter vena sentral. Setelah semua sampel diperoleh, dilakukan eutanasia menggunakan kalium klorida sebanyak $20 \mathrm{ml}$ melalui kateter vena sentral. Pengambilan sampel darah dilakukan pada saat setelah induksi anestesi (penapisan), saat gejala sepsis terlihat, dan 3 jam setelah dilakukan resusitasi cairan. Sampel darah yang diambil selanjutnya dianalisis menggunakan hematology blood analyzer.

\section{- HASIL DAN PEMBAHASAN}

Hasil yang diperoleh menunjukkan tidak ada perbedaan nyata rataan jumlah eritrosit, hemoglobin, hematokrit, volume eritrosit rata-rata (VER), hemoglobin eritrosit ratarata (HER), dan konsentrasi hemoglobin eritrosit rata-rata (KHER) antar kelompok perlakuan maupun antar waktu pengambilan sampel darah (Tabel 1). Terjadi kecenderungan penurunan rataan jumlah eritrosit, rataan nilai hemoglobin, dan rataan nilai hematokrit pada kedua kelompok saat sepsis. Keadaan sepsis dapat menyebabkan perusakan membran eritrosit (Piagnerelli et al. 2007). Kerusakan membran eritrosit terjadi ketika produksi reactive oxygen species (ROS) melebihi pertahanan antioksidan dari jaringan akibat kondisi inflamasi. Reactiveoxygen species (ROS) yang termasuk superoxide anion (O2-), hydroxyl radical (OH-), dan hydrogen peroxide ( $\mathrm{H} 2 \mathrm{O} 2)$ yang dihasilkan oleh aktivasi leukosit dapat merusak $\mathrm{Hb}$ dan menginduksi hemolisis setelah lebih dari 5 jam produksi ROS (Piagnerelli et al. 2007).

Tabel 1 Nilai indeks eritrosit

\begin{tabular}{|c|c|c|c|c|c|c|}
\hline \multirow{2}{*}{$\begin{array}{l}\text { Para- } \\
\text { meter }\end{array}$} & \multicolumn{3}{|c|}{ MFG } & \multicolumn{3}{|c|}{ RAM } \\
\hline & $\mathbf{T}$ & $\mathbf{S}$ & $\mathbf{R}$ & $\mathbf{T}$ & $\mathbf{S}$ & $\mathbf{R}$ \\
\hline $\begin{array}{c}\mathrm{RBC} \\
\left(\mathrm{x} 10^{6} \mu \mathrm{l}\right)\end{array}$ & $4.3 \pm 1.3$ & $3.8 \pm 1.0$ & $3.7 \pm 1.0$ & $4.9 \pm 0.7$ & $4.0 \pm 0.9$ & $4.6 \pm 1.0$ \\
\hline $\begin{array}{c}\mathrm{Hb} \\
(\mathrm{g} / \mathrm{dL} 0\end{array}$ & $11.3 \pm 4.7$ & $10.1 \pm 3.9$ & $8.8 \pm 2.2$ & $11.9 \pm 3.5$ & $11.0 \pm 2.1$ & $12.2 \pm 3.1$ \\
\hline $\begin{array}{l}\text { PCV } \\
(\%)\end{array}$ & $32.4 \pm 10.9$ & $29.7 \pm 12.2$ & $26.0 \pm 6.8$ & $36.6 \pm 10.3$ & $33.4 \pm 6.21$ & $36.5 \pm 9.42$ \\
\hline $\begin{array}{l}\text { VER } \\
\text { (fL) }\end{array}$ & $75.9 \pm 14.9$ & $77.2 \pm 16.7$ & $71.4 \pm 21.0$ & $76.7 \pm 18.4$ & $78.1 \pm 10.7$ & $78.1 \pm 10.3$ \\
\hline $\begin{array}{c}\text { HER } \\
(\mathrm{pg})\end{array}$ & $26.1 \pm 5.7$ & $26.5 \pm 5.0$ & $26.6 \pm 7.5$ & $25.4 \pm 5.6$ & $25.6 \pm 3.9$ & $25.9 \pm 4.2$ \\
\hline $\begin{array}{c}\text { KHER } \\
(\%)\end{array}$ & $34.3 \pm 2.7$ & $34.2 \pm 1.3$ & $34.0 \pm 2.3$ & $32.3 \pm 0,9$ & $32.1 \pm 1.4$ & $32.9 \pm 1.4$ \\
\hline
\end{tabular}

Keterangan: RBC (eritrosit), Hb (hemglobin), PCV (hematokrit), T (penapisan), $\mathrm{S}$ (sepsis), R (3 jam setelah resusitasi)

Penelitian ini menggunakan cairan koloid (MFG4\%) dan kristaloid (RAM) untuk mengatasi gejala sepsis denganmengoptimalkan hemodinamik dalam 6 jam pertama dikenal sebagai early goal therapy. Kedua cairan tidak secara nyata mempengaruhi nilai indeks eritrosit. Terjadi kecenderungan penurunan rataan jumlah eritrosit, rataan nilai hemoglobin, dan rataan nilai hematokrit pada 3 jam setelah resusitasi cairan koloid. Kencenderungan penurunan ini terjadi karena cairan koloid bermolekul besar dan mempunyai tekanan onkotik yang tinggi sehingga akan menetap lebih lama didalam pembuluh darah (Leksana 2009). DiBartola (2012) menyatakan bahwa sampai 5 jam setelah administrasi cairan koloid secara intravena masih terdapat sekitar $50 \%$ dari volume yang diadministrasikan tetap dalam pembuluh darah. Cairan koloid yang menetap lama pada pembuluh darah akan meningkatkan volume plasma lebih lama dan menyebabkan turunnya nilai hematokrit akibat terjadinya hemodilusi. Peningkatan volume plasma menyebabkan menurunnya konsentrasi hematokrit, nilai hemoglobin, dan jumlah eritrosit, tetapi tidak menurunkan jumlah absolut hemoglobin dan jumlah eritrosit dalam sirkulasi (Ettinger dan Eldman2009).

Terjadi kecenderungan kenaikan rataan jumlah eritrosit, rataan nilai hemoglobin, dan rataan nilai hematokrit pada 3 jam setelah resusitasi cairan kristaloid. Kencenderungan kenaikan ini terjadi karena cairan kristaloid bermolekul kecil sehingga cairan ini akan menyeberangi membran pembuluh darah dan memasuki kompartemen interstitial (Leksana 2009). Silverstein (2009) menyatakan bahwa 1 jam setelah administrasi cairan kristaloid secara intravena hanya $20-25 \%$ dari volume yang diadministrasikan tetap dalam pembuluh darah. Berpindahnya cairan plasma ke interstitial akan mengurangi cairan plasma pada intravaskular dan akan mengembalikan jumlah eritrosit, konsentrasi hemoglobin dan nilai hematokrit.

Menurut hasil yang didapatkan jumlah dan nilai indeks eritrosit anak babiberupa penurunan jumlah eritrosit, kenaikan nilai VER, dan nilai KHER yang sedikit di atas normal dapat dikatakan anak babi mengalami anemia makrositik normokromik.

\section{- SIMPULAN}

Anak babi berada dalam proses persembuhan dari anemia makrositik regeneratif karena tidak ditemukan adanya gejala klinis anemia dan nilai VER yang di atas rentang referensi normal. Resusitasi cairan koloid (MFG 4\%)dan kristaloid (RAM) tidak mempengaruhi nilai indeks eritrosit secara nyata.

\section{- INFORMASI PENULIS}

Penulis untuk Korespondensi

gunanti.soe@gmail.com

\section{- PUSTAKA ACUAN}

Dewi R. 2015. Pengaruh cairan koloid atau kristaloid terhadap kejadian acuterespiratory distress syndrome pada hewan coba Sus scrofa dengan sepsisberat: Kajian pada extravascular lung water, IL-8, dan VCAM-1 [disertasi]. Jakarta (ID): Universitas Indonesia.

DiBartola SP. 2012. Fluid, Electrolyte, and Acid Base Disorders in Small Animal Practice. Missouri (US): Elsevier Saunders.

Ettinger SJ, Edelman EC. 2009. Textbook of Veterinary Internal Medicine. Ed ke-7. California (US): Elsevier Health Sciene.

Leksana E. 2009. SIRS, Sepsis, Keseimbangan Asam-Basa, Syok dan Terapi Cairan. Semarang (ID): CPD IDSAI Jateng-Bagian Anestesi dan Terapi Intensif FK Undip.

Piagnerelli M, Boudjeltia KZ, Gulbis B, Vanhaeverbeek M, Vincent JL. 2007. Anemia in sepsis: the importance of red blood cell membrane changes. Transfus Altern Transfus Med. 9: 143-149.

Silverstein DC. 2009. Daily Intrvenous Fluid Therapy. Di dalam: Small Animals Critical Care Medicine. 271-280. Missouri (US): Saunders.

Vincent JL, Abraham E. 2006. The last 100 years of sepsis. Am J Respir Crit Care Med. 173: 256-263.

Voigt GL, Swist SL. 2011. Hematology Techniques and Concepts for Veterinary Technicians. Ed ke-2. West Sussex (UK): Wiley-Blackwell. 